Prystrom J., Samorzad terytorialny i gospodarczy jako podmiot determinujacy innowacyjnośc i kondycje gospodarczq na przyktadzie gospodarki szwedzkiej, „Ekonomia i Prawo”, Polszakiewicz B., Boehlke J. (red.), Tom XII, nr 1/2013, ss. 81-92 DOI: http://dx.doi.org/10.12775/EiP.2013.007

\title{
SAMORZĄD TERYTORIALNY I GOSPODARCZY JAKO PODMIOT DETERMINUJACY INNOWACYJNOŚĆ I KONDYCJĘ GOSPODARCZA NA PRZYKŁADZIE GOSPODARKI SZWEDZKIEJ
}

\section{STRESZCZENIE}

Innowacyjność gospodarki można określić mianem determinanty rozwoju gospodarczego w regionie. Działalność innowacyjna podmiotów gospodarczych skutkuje bowiem możliwością ich rozwoju. Osiągane efekty stają się kuszącymi dla pozostałych przedsiębiorstw i skutkują podjęciem innowacyjnej aktywności. To z kolei przyczynia się do rozwoju gospodarczego w danym regionie.

Niestety działalność innowacyjna spotyka na swojej drodze różnego rodzaju utrudnienia. Niezastąpionym w tym przypadku okazuje się być wsparcie otoczenia instytucjonalnego, obejmującego samorząd terytorialny i gospodarczy.

Celem niniejszego artykułu jest przedstawienie znaczenia samorządu terytorialnego i gospodarczego jako elementu otoczenia instytucjonalnego, determinującego innowacyjność lokalnych podmiotów gospodarczych, a zarazem rozwój gospodarczy w danym regionie, na przykładzie gospodarki szwedzkiej - od lat postrzeganej za jedną z najbardziej innowacyjnych i konkurencyjnych na świecie.

Słowa kluczowe: samorząd terytorialny, samorząd gospodarczy, innowacyjność, kondycja gospodarcza

Klasyfikacja JEL: O1, O2, O3, Z18

* Joanna Prystrom, Politechnika Białostocka, Wydział Zarządzania, Katedra Ekonomii i Nauk Społecznych, ul. Ojca Tarasiuka 2, 16-001 Kleosin, e-mail: j.prystrom@pb.bialystok.pl. 


\title{
LOCAL AND ECONOMIC GOVERNMENT AS THE DETERMINANT OF INNOVATION AND ECONOMIC CONDITION: CASE STUDY OF SWEDISH ECONOMY
}

\author{
SUMMARY
}

Innovativeness of the economy can be described as a determinant of economic development in the region. Businesses innovative activity results in the possibility of their development. Achieved results are tempting for other companies and lead to the undertaking of innovative activity. This in turn contributes to the economic development in the region.

Unfortunately, innovative activity comes up against a variety of difficulties. Institutional support including local and economic government, appears to be indispensable in that case.

The aim of this paper is to present the essence of local and economic government as part of the institutional environment, which determines innovativeness of local businesses, and also economic development in the region, for example, the Swedish economy - for years perceived as one of the most innovative and competitive in the world.

Keywords: local government, economic government, innovativeness, economic condition

JEL Classification: O1, O2, O3, Z18

\section{WSTĘP}

Innowacyjność gospodarki można określić mianem determinanty rozwoju gospodarczego w regionie. Działalność innowacyjna podmiotów gospodarczych skutkuje bowiem możliwością ich rozwoju poprzez m. in. zaoferowanie nowego produktu bądź usługi będących odpowiedzią na stale zmieniające się oczekiwania klientów, unowocześnienie linii produkcyjnej, czy też wejście na nowe rynki zbytu. Dzięki temu rozwijające się przedsiębiorstwa przyciągają inwestorów i klientów zarówno z kraju, jak i zagranicy. To z kolei przekłada się np. na możliwość zmniejszenia bezrobocia, a w następstwie może przyczynić się do rozwoju gospodarczego.

Niestety działalność innowacyjna spotyka na swojej drodze różnego rodzaju utrudnienia. Wśród nich można wyróżnić ograniczenia finansowe realizacji innowacyjnych projektów, czy też brak wykwalifikowanego personelu.

Niezastąpionym w tym przypadku okazuje się być wsparcie otoczenia instytucjonalnego, obejmującego samorząd terytorialny, czyli różnego rodzaju in- 
stytucje i urzędy, jak również samorząd gospodarczy, w ramach którego wyróżnia się przedsiębiorstwa i różnorodne formy ugrupowań przedsiębiorców działających na rzecz wspierania działań prorozwojowych w regionie.

Celem niniejszego artykułu jest przedstawienie istoty samorządu terytorialnego i gospodarczego jako elementu otoczenia instytucjonalnego, determinującego innowacyjność lokalnych podmiotów gospodarczych, a zarazem rozwój gospodarczy, na przykładzie gospodarki szwedzkiej - od lat postrzeganej za jedną z najbardziej innowacyjnych i konkurencyjnych na świecie.

\section{ISTOTA I REALIA INNOWACJI WE WSPÓŁCZESNEJ GOSPODARCE}

W ostatnich dekadach można zaobserwować wzrost znaczenia innowacji w procesach gospodarczych. Co istotne, proces ten odnosi się do wielu sfer życia wpływając nie tylko na dynamikę rozwoju, ale również na postrzeganie przyszłych tendencji gospodarczych i społecznych. Wyznacza także ścieżki, którymi gospodarki powinny podążać w celu osiągania coraz lepszych efektów ${ }^{1}$.

Innowacja to wprowadzanie nowego produktu, modyfikacja dotychczasowych, wprowadzanie nowej metody produkcji, uzyskanie nowych źródeł i możliwości, wykorzystanie nietkniętych do tej pory obszarów i rynków czy też nowe sposoby organizacji biznesu².

Dzięki innowacyjności dany podmiot staje się konkurencyjny względem krajowych przeciwników. Poprzez to skłania do poczynań innowacyjnych pozostałe firmy, co skutkuje napędzeniem koniunktury gospodarczej. To wszystko z kolei przekłada się na wzmocnienie konkurencyjnej pozycji kraju na arenie międzynarodowej ${ }^{3}$.

Nieuniknionym jest fakt, iż chęci i zapał podmiotów gospodarczych do podjęcia i realizowania działalności innowacyjnej, często są osłabiane i uniemożliwiane przez różne utrudnienia. Wśród przeszkód można wyróżnić czynniki ekonomiczne, rynkowe, oddziaływanie związane $z$ wiedzą czy też występujący dosyć często brak źródeł finansowania innowacyjności (rysunek 1.).

Warunki instytucjonalno-rynkowe tworzą klimat dla rozwoju przedsiębiorczości i konkurencyjności w gospodarce. Podstawowe znaczenie odgry-

\footnotetext{
1 J. Prystrom, Innowacyjne determinanty funkcjonowania rynku pracy na przyktadzie gospodarki szwedzkiej, Oficyna Wydawnicza Politechniki Białostockiej, Białystok 2012, s. 5.

2 J. A. Schumpeter, The Theory of Economic Development, Galaxy Book, New York 1932, s. 66.

3 J. Prystrom, Dziatalnośc innowacyjna a konkurencyjność polskich podmiotów gospodarczych, [w:] J. Czech-Rogosz (red.), Koniunktura gospodarcza a reakcje podmiotów gospodarujacych, Wydawnictwo Akademii Ekonomicznej w Katowicach, Katowice 2009, s. 240.
} 
wają mechanizm rynkowy oraz otwartość gospodarki, które sprzyjają, a nawet zmuszają podmioty gospodarcze do wprowadzania innowacji. Równocześnie tak funkcjonujący rynek musi mieć nowoczesną i pełną infrastrukturę rynkową, dostosowaną do wymogów dynamicznych przedsiębiorstw innowacyjnych. Powinna ona zapewnić nowatorskim podmiotom gospodarczym dostęp do różnorodnych zasobów, pozwalających na wprowadzanie innowacji i uzyskanie przewagi konkurencyjnej ${ }^{4}$.

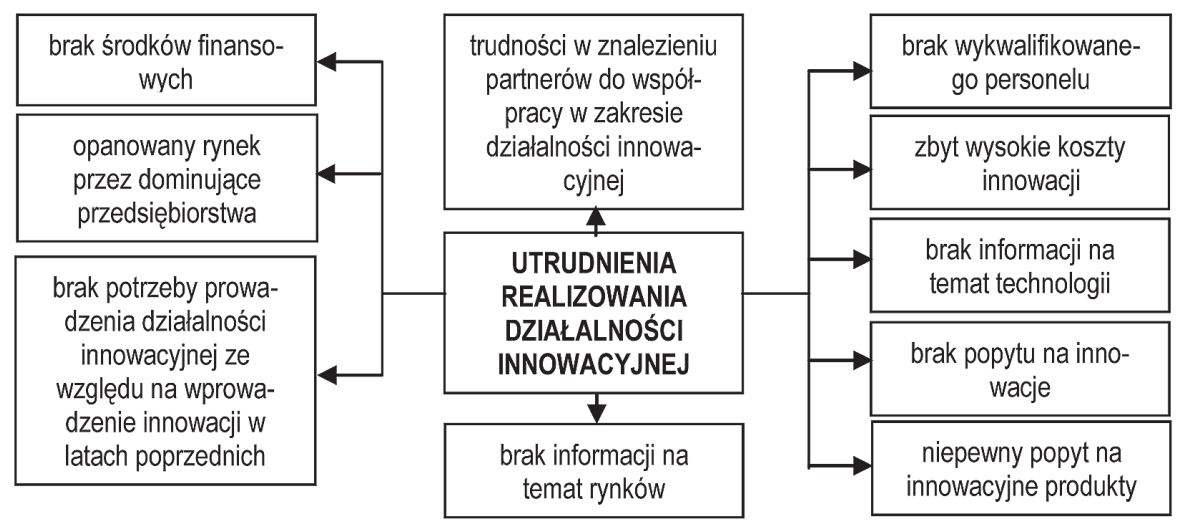

Rysunek 1. Utrudnienia realizowania działalności innowacyjnej

Źródło: opracowanie własne na podstawie: B. H. Hall, Policy for innovation: insights from economic research, http:// www.vinnova.se/upload/dokument/VINNOVA_gemensam/Kalender/2008/Seminarium\%204\%2C\%2012\%20 juni/4\%20juni\%20filmer\%2C\%20PPT/Sweden_4Jun2008_Bronwyn\%20Hall.pdf, 14.07.2009 r.; Reason for which enterprises did not carry out innovation activities 2002-2004, http://www.scb.se/templates/table OrChart_222609.asp, 04.07.2008 r. i danych z Głównego Urzędu Statystycznego.

Istotną rolę $\mathrm{w}$ tym przypadku odgrywa otoczenie instytucjonalne, w zestaw którego wchodzi szereg składników o bardzo zróżnicowanym charakterze działalności, będących dla innowacyjnego przedsiębiorstwa zewnętrznymi źródłami informacji, technologii i doradztwa. Ogólnie rzecz ujmując, na otoczenie składają się instytucje i organizacje zajmujące się wspieraniem i pośrednictwem w dziedzinie innowacji. Należą do nich instytucje rządowe i regionalne oraz instytucje i organizacje pozarządowe, takie jak ośrodki wspomagania przedsiębiorczości i innowacji, parki i inkubatory technologiczne, centra technologiczne, ośrodki doradztwa i szkoleń, informacji itp. Innym elementem otoczenia instytucjonalnego innowacyjności są organizacje regio-

${ }^{4}$ Otoczenie instytucjonalne małych firm innowacyjnych, „Gazeta Innowacje”, nr 18, http:// imik.wip.pw.edu.pl/innowacje18/strona10.htm, 07.07.2009 r. 
nalne, do których można zaliczyć inkubatory przedsiębiorczości, centra transferu technologii, centra doskonałości i specjalne strefy ekonomiczne ${ }^{5}$.

\section{SAMORZĄD TERYTORIALNY I GOSPODARCZY W SZWECJI - EFEKTY ODDZIAŁYWANIA W ODNIESIENIU DO INNOWACYJNOŚCI GOSPODARKI SZWEDZKIEJ}

Z prowadzonych badań wynika, że źródłem innowacji coraz częściej nie są przedsiębiorstwa, lecz środowisko o charakterze niegospodarczym. Innowacja wymaga partnerstwa, bez relacji współpracy z partnerami - nie tylko kooperantami, ale i lokalnymi czy regionalnymi samorządami, kreacja i dyfuzja innowacji nie jest możliwa. Konieczne jest inwestowanie w kontakty - tutaj szczególną rolę mają do spełnienia ośrodki innowacji. Aby mogły one realizować swoją misję, ich działalność musi być uwzględniana przez pozostałe podmioty systemu innowacyjnego, w tym przez władze rządowe i samorządowe ${ }^{6}$.

Zależności, jakie zachodzą między instytucjami naukowo-badawczymi, a administracją lokalną i regionalną oraz środowiskiem biznesu, bardzo ciekawie zobrazował K. B. Matusiak (rysunek 2.).

W ramach wspomnianej współpracy uwzględniono między innymi istotę wiedzy, kapitału ludzkiego, który stanowi poniekąd podstawę zdolności innowacyjnej. We wzajemnym oddziaływaniu na rzecz innowacyjności gospodarki ważną kwestię odgrywa także administracja lokalna i regionalna, którą można określić mianem samorządu terytorialnego, który nicuje i koordynuje działania proinnowacyjne oraz oferuje różnego rodzaju programy wsparcia działalności innowacyjnej podmiotów gospodarczych. Nie można również pominąć środowiska biznesu, w skład którego wchodzi szereg różnorodnych przedsiębiorstw, oferujących na rynku równie zróżnicowane towary i usługi. To właśnie grono biznesu jest odbiorcą opracowanych technologii i innowacji. Co istotne, w znacznej mierze jest ważniejszym podmiotem finansującym aktywność naukowo-badawczą, która owocuje nowo opracowywanymi innowacjami.

Powyższe instytucje i podmioty śmiało można określić mianem podmiotów samorządu terytorialnego i gospodarczego, tworzącego swego rodzaju otoczenie instytucjonalne innowacyjności. Jak już wspomniano do głównych elementów tego otoczenia można zaliczyć instytucje rządowe. Ważną rolę od-

5 Ibidem.

${ }^{6}$ M. Nowak, M. Mażewska, Sz. Mazurkiewicz, Wspótpraca ośrodków innowacji z administracja publicznq, PARP, Łódź-Gdańsk-Kielce 2011, s. 14, http://www.pi.gov.p1/PARPFiles/file/OIB/ SOIB/Publikacje/PARP_BIOS_T25_broszura_Wspolpraca_z_admistracja.pdf, 24.06.2012 r. 
grywają również jednostki oferujące wsparcie finansowe umożliwiające realizację nowatorskiej aktywności wśród krajowych przedsiębiorstw. Odpowiedni poziom krajowej innowacyjności jest także w znacznej mierze uzależniony od uczelni wyższych i krajowych instytutów badawczych. Jedne z elementów otoczenia można określić mianem twórców innowacji, inne warunkują innowacyjność podmiotów gospodarczych finansując działalność B+R, którą realizują jednostki naukowe. Otoczenie innowacyjności w gospodarce szwedzkiej spróbowano rozpisać w tabeli 1.

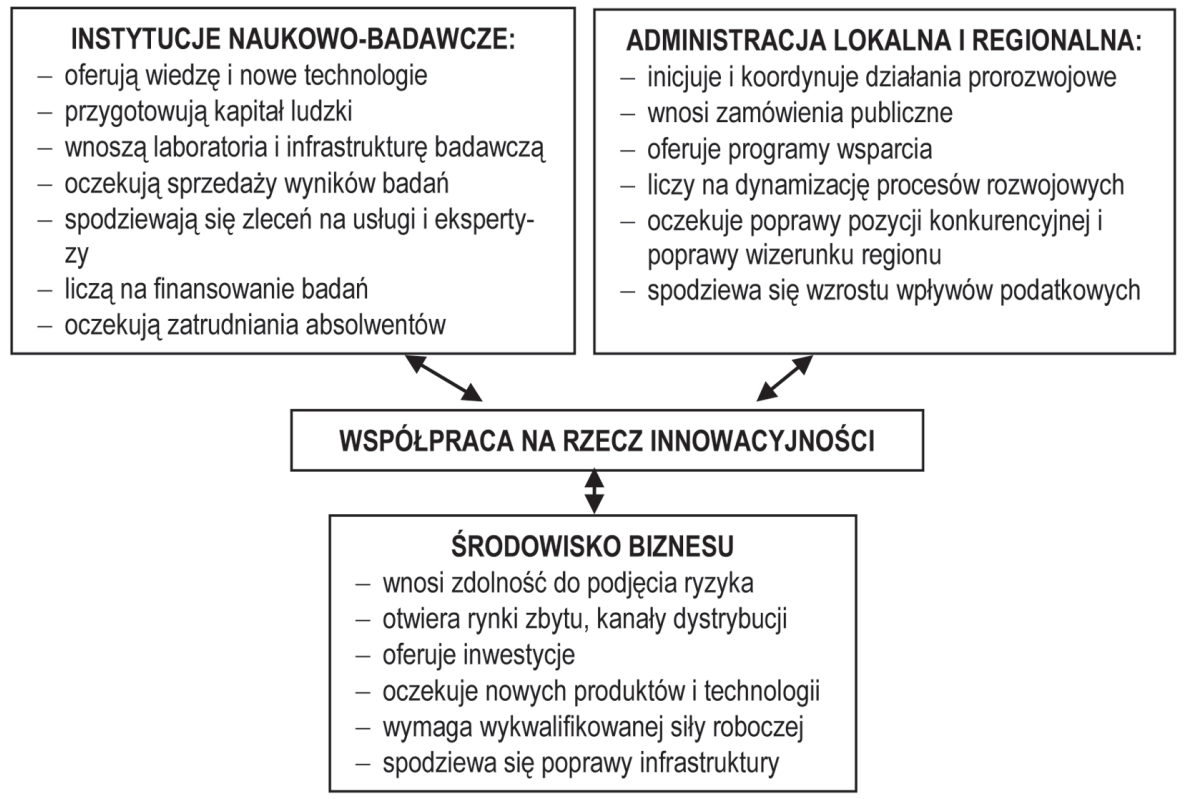

Rysunek 2. Wspótpraca instytucji naukowo-badawczych, administracji lokalnej i regionalnej ze środowiskiem biznesu na rzecz innowacyjności gospodarki

Źródło: opracowanie własne na podstawie: K. B. Matusiak, Budowa powiązań nauki z biznesem w gospodarce opartej na wiedzy, SGH, Warszawa 2011, s. 211.

Rząd szwedzki wraz z poszczególnymi ministerstwami i Szwedzką Radą Badawczą odpowiadają za opracowywanie krajowej polityki innowacyjnej. Instytucje VINNOVA bądź NUTEK jako elementy otoczenia instytucjonalnego innowacyjności w Szwecji w znacznej mierze odpowiadają za kwestię finansowania i wspierania działalności innowacyjnej w kraju. Z kolei jednostki naukowe są odpowiedzialne za ogniwo krajowej innowacyjności kształcąc wyposażonych w umiejętności badawcze obywateli i realizując działalność B+R, czego owocami są opracowane innowacje. Odbiorcami nowatorskich opraco- 
wań są natomiast zarówno przedsiębiorstwa, jak również instytuty bądź towarzystwa naukowe. Pierwsze $z$ nich wykorzystują innowacje do usprawniania własnej działalności i wzmocnienia kondycji gospodarczej względem konkurencji. Prywatna sfera badawczo-naukowa wykorzystuje rezultaty innowacyjnej aktywności w celu realizacji swojej indywidualnej działalności innowacyjnej

Tabela 1. Otoczenie instytucjonalne działalności innowacyjnej w Szwecji

\begin{tabular}{|c|c|}
\hline \multicolumn{2}{|c|}{ ОTOCZENIE INSTYTUCJONALNE } \\
\hline INSTYTUCJA & CHARAKTER ODDZIALYWANIA \\
\hline $\begin{array}{c}\text { Parlament } \\
\text { Rząd } \\
\text { Ministerstwo Nauki i Badań } \\
\text { Ministerstwo Przedsiębiorczości, Energii i Komunikacji } \\
\text { Szwedzka Rada Badawcza }\end{array}$ & Sektor publiczny i twórcy polityki innowacyjnej \\
\hline $\begin{array}{l}\text { NUTEK } 1 \\
\text { VINNOVA } \\
\text { ITPS }^{3} \\
\text { ALMI }^{4}\end{array}$ & Finansowanie \\
\hline $\begin{array}{l}\text { Uczelnie wyższe } \\
\text { Instytuty badawcze }\end{array}$ & Jednostki działające \\
\hline $\begin{array}{c}\text { Przedsiębiorstwa } \\
\text { Instytuty badawcze } \\
\text { Fundacje } \\
\text { Towarzystwa naukowe }\end{array}$ & Sektor prywatny \\
\hline
\end{tabular}

${ }^{1}$ NUTEK to centralna władza publiczna w Szwecji zajmująca się rozwojem przedsiębiorczości; ${ }^{2}$ VINNOVA - Szwedzka Agencja ds. Systemów Innowacji to rządowa agencja, której kluczowym założeniem jest promowanie rozwoju i aktywności wzrostowej w krajowych podmiotach gospodarczych z całej Szwecji; ${ }^{3}$ ITPS to Szwedzki Instytut Badań nad Polityką Wzrostu, który dąży do podnoszenia konkurencyjności podmiotów gospodarczych poprzez realizację polityki rozwoju za pomocą analiz ekonomicznych i technicznych zmian, oceny politycznych posunięć i zapewnienia, że jakość prowadzonych badań i dostępność ich efektów przekładają się na rozwój gospodarczy; ${ }^{4}$ ALMI to instytucja państwowa, która oferuje podmiotom gospodarczym zarówno pomoc przy rozwijaniu swojego biznesu poprzez doradztwo, nawiązywanie kontaktów z innymi podmiotami oraz opracowywanie programów rozwoju, jak również wsparcie finansowe. W działalności ALMI znajduje się również udzielanie pożyczek finansowych dla innowatorów i wynalazców w celu wspierania ich aktywności innowacyjnej.

Źródło: opracowanie własne na podstawie: B. Mikołajczyk, M. Zaręba, Otoczenie instytucjonalne dla rozwoju innowacyjności w Finlandii, „Studia Europejskie”, 2005, nr 3, s. 93.

Wśród efektów oddziaływania omówionych instytucji można wyróżnić podnoszenie wiedzy czy poziomu realizowanych prac B+R. Jako kryterium oddziaływania szwedzkiego samorządu terytorialnego i gospodarczego można zastosować porównanie sytuacji gospodarki Szwecji na tle Danii i Norwegii pod względem poziomu szkolnictwa wyższego, dostępności do badań i szko-

\footnotetext{
${ }^{7}$ J. Prystrom, Innowacyjne..., s. 65.
} 
leń, jakości prac B+R, zdolności technologicznej i innowacyjności, które skutkują między innymi możliwością rozwoju krajowych podmiotów gospodarczych, a tym samym szansą zwiększenia zatrudnienia (tabela 2.).

Tabela 2. Wybrane efekty oddziaływania otoczenia instytucjonalnego w Szwecji, Danii i Norwegii według rankingu Światowego Forum Ekonomicznego 2008-2009

\begin{tabular}{|c|c|c|c|}
\hline KRAJ & $\begin{array}{c}\text { POZIOM SZKOLNICTWA } \\
\text { I KSZTALCENIA ZAWODOWEGO }\end{array}$ & $\begin{array}{c}\text { LOKALNA DOSTEPNOŚĆ́ } \\
\text { DO BADAŃ I SZKOLEŃ }\end{array}$ & $\begin{array}{c}\text { JAKOŚĆ PRAC B+R } \\
\text { REALIZOWANYCH W INSTYTUCJACH }\end{array}$ \\
\hline Dania & 2 & 6 & 12 \\
\hline Norwegia & 10 & 18 & 22 \\
\hline Szwecja & 3 & 7 & 11 \\
\hline Kraj & Zdolność technologiczna & Innowacyjność & Efektywność rynku pracy \\
\hline Dania & 3 & 10 & 5 \\
\hline Norwegia & 4 & 19 & 14 \\
\hline Szwecja & 2 & 5 & 26 \\
\hline
\end{tabular}

Źródło: M. Porter, K. Schwab K., The Global Competitiveness Report 2008-2009, World Economic Forum, Geneva 2008, s. 148-149; 264-265; 311-312; http://www.weforum.org/pdf/GCR08/GCR08.pdf, 23.03.2010 r.

Jak widać, oddziaływanie instytucji wspierających innowacyjność i transfer technologii w krajowych podmiotach gospodarczych może wpływać między innymi na ich zdolność technologiczną, a w następstwie kraju, plasując Szwecję na 2 miejscu wśród 134 gospodarek. Instytucje transferu technologii dążąc do podnoszenia poziomu wykształcenia i kwalifikacji obywateli, pomogły gospodarce szwedzkiej wypaść pomyślnie pod względem poziomu szkolnictwa wyższego i kształcenia zawodowego podnoszącego umiejętności i kwalifikacje pracowników. W tym przypadku, Szwecja zajęła w zestawieniu lokatę 3. Istotną rolę odgrywa także dostępność do badań i szkoleń, jakość realizowanych prac B+R, które w rezultacie determinują innowacyjność i kondycję gospodarki, a tym samym efektywność rynku pracy.

Tabela 3. Innowacyjność gospodarki szwedzkiej na przestrzeni lat 2003-2011 według Europejskiego Rankingu Innowacyjności

\begin{tabular}{|c|c|c|c|c|c|c|c|c|c|}
\hline RoK & 2003 & 2004 & 2005 & 2006 & 2007 & 2008 & 2009 & 2010 & 2011 \\
\hline Miejsce w rankingu & 2 & 2 & 1 & 1 & 1 & 1 & 1 & 1 & 1 \\
\hline
\end{tabular}

Źródło: opracowanie własne na podstawie: European Innovation Scoreboard 2003-2007, http://www.proinno-europe. eu/index. $f$ m?fuseaction=page.display\&topic $I D=5 \&$ parentID $=51,29.06 .2009$ r.; European innovation scoreboard 2008. Comparative analysis of innovation Performance, European Communities, Luxembourg 2009, s. 6, http://www.eis.eu/, 29.03.2010 r.; European Innovation Scoreboard 2009, European Communities, Luxembourg 2009, s. 3, http://ec.europa.eu/enterprise/newsroom/cf/_getdocument.cfm?doc_id=5714, 23.02 .2012 r.; Innovation Union Scoreboard 2010, http://www.proinno-europe.eu/inno-metrics/page/1-executive-summary, 23.02.21012 r.; Innovation Union Scoreboard 2011, http://www.proinno-europe.eu/inno-metrics/page/1executive-summary-0, 23.02.21012 r. 
W rezultacie gospodarka szwedzka w 2001 roku została uznana przez EIS za kraj o najwyższym poziomie realizowanych prac B+R. Rok później, Szwecję okrzyknięto liderem również pod względem poziomu działalności badawczo-rozwojowej, jak i innowacyjności ${ }^{8}$.

Od 2005 roku Szwecja jest niepodważalnym liderem, jeżeli chodzi o innowacyjność krajowej gospodarki. Dwa lata wcześniej kraj znalazł się w niemal równie podobnej sytuacji, plasując się na drugim miejscu w Europejskim Rankingu Innowacyjności. Co ważne, w latach ubiegłych Szwecja znajdowała się również w gronie innowacyjnych liderów ${ }^{9}$.

\section{INNOWACYJNOŚĆ GOSPODARKI SZWEDZKIEJ NA ARENIE MIĘDZYNARODOWEJ}

Innowacje umożliwiają rozwój przedsiębiorstw, zwiększenie produkcji, wchodzenie na nowe rynki zbytu lub wzmocnienie udziału na dotychczas zajmowanych, czy zwiększenie zatrudnienia. To natomiast przyczynia się do zmniejszenia bezrobocia, zachęcenia i napływu inwestorów, co owocuje wzmocnieniem kondycji gospodarczej kraju.

Tabela 4. Światowy Ranking Konkurencyjności według WEF (Global Competitiveness Index) 2009-2011

\begin{tabular}{|c|c|c|}
\hline Państwo & $\begin{array}{c}\text { MiejSCE W RANKINGU 2009-2010 } \\
\text { (WŚRÓd 133 PAŃSTW) }\end{array}$ & $\begin{array}{c}\text { MieJSCE W RANKINGU 2010-2011 } \\
\text { (WŚRód 139 PAŃSTW) }\end{array}$ \\
\hline Szwajcaria & 1 & 1 \\
\hline Szwecja & 4 & 2 \\
\hline Singapur & 3 & 4 \\
\hline USA & 2 & 5 \\
\hline Niemcy & 7 & 6 \\
\hline Japonia & 8 & 8 \\
\hline Finlandia & 6 & 9 \\
\hline Holandia & 10 & 10 \\
\hline Dania & 5 & \\
\hline Kanada & 9 & \\
\hline
\end{tabular}

Źródło: K. Schwab, The Global Competitiveness Report 2010-2011, World Economic Forum, Geneva 2010, s. 15, http://www3.weforum.org/docs/WEF_GlobalCompetitivenessReport_2010-11.pdf, 21.02.2012 r.

8 European Innovation Scoreboard 2001, European Commission, Luxembourg 2001, s. 3 i European Innovation Scorebard 2002, European Commission, Luxembourg 2002, s. 3.

${ }^{9}$ Wyniki EIS z lat 1999-2002 mówią, iż gospodarka szwedzka znajdowała się w gronie najbardziej innowacyjnych na świecie, aczkolwiek nie odnaleziono dokładnych informacji odnośnie zajmowanych lokat. 
Można zauważyć, że za najbardziej konkurencyjne gospodarki uznano Szwajcarię, Szwecję, Singapur, Niemcy, Japonię, Finlandię, Holandię, Danię oraz Kanadę.

Tabela 5. Światowy indeks konkurencyjności pod względem innowacyjności 2010-2011

\begin{tabular}{|c|c|c|}
\hline PAŃSTwO & GCI 2010-2011 & MIEJSCE W RANKINGU \\
\hline Szwajcaria & 1 & 5 \\
\hline Szwecja & 2 & 9 \\
\hline Singapur & 3 & 1 \\
\hline USA & 4 & 8 \\
\hline Niemcy & 5 & 4 \\
\hline Japonia & 6 & 3 \\
\hline Finlandia & 7 & 13 \\
\hline Holandia & 8 & 10 \\
\hline Dania & 9 & 11 \\
\hline Kanada & 10 & \\
\hline
\end{tabular}

Źródło: jak w tabeli 4., s. 22.

Jak wcześniej wskazano, innowacje stanowią ważną determinantę konkurencyjności zarówno nowatorskich przedsiębiorstw, jak również państw kładących istotny nacisk na innowacyjność we wszelkich sferach jego poczynań. Tabela 6. przedstawia klasyfikację konkurencyjności 10 najsilniejszych gospodarek ze względu na poziom innowacyjności.

Tabela 6. Ranking innowacyjności krajowych gospodarek w 2011 roku

\begin{tabular}{|c|c|}
\hline KRA & MIESCE W RANKINGU \\
\hline Szwecja & 1 \\
\hline Dania & 2 \\
\hline Niemcy & 3 \\
\hline Finlandia & 4 \\
\hline Belgia & 5 \\
\hline Wielka Brytania & 6 \\
\hline Holandia & 7 \\
\hline Austria & 8 \\
\hline Luksemburg & 9 \\
\hline Irlandia & 10 \\
\hline
\end{tabular}

Źródło: opracowanie własne na podstawie: Innovation Union Scoreboard 2011, http://www.proinno-europe.eu/ inno-metrics/page/1-executive-summary-0, 23.02.21012 r.

Godny uwagi jest także Europejski Ranking Innowacyjności, z godnie z którym w 2011 roku za najbardziej innowacyjną gospodarkę uznano go- 
spodarkę Szwecji. Zaraz za nią, w pierwszej dziesiątce uplasowały się Dania, Niemcy, Finlandia, Belgia, Wielka Brytania, Holandia, Austria, Luksemburg i Irlandia.

$\mathrm{Z}$ prowadzonych badań wynika, że innowacja wymaga partnerstwa. Bez współpracy z partnerami - nie tylko kooperantami, ale i lokalnymi czy regionalnymi samorządami, kreacja i dyfuzja innowacji nie jest możliwa. Konieczne jest inwestowanie w kontakty - tutaj szczególną rolę mają do spełnienia ośrodki innowacji. Aby ośrodki te mogły realizować swoją misję, ich działalność musi być uwzględniana przez pozostałe podmioty systemu innowacyjnego, w tym przez władze rządowe i samorządowe ${ }^{10}$.

\section{ZAKOŃCZENIE}

Analizując przykład gospodarki szwedzkiej można ośmielić się stwierdzić, że należycie funkcjonujące otoczenie działalności innowacyjnej podmiotów gospodarczych, które pobudza współpracę instytucji naukowo-badawczych z samorządem terytorialnym i gospodarczym, stanowi jedną z ważniejszych determinant wysokiego poziomu innowacyjności krajowej gospodarki.

Środowisko naukowo-badawcze zapewnia odpowiednio uzbrojony w niezbędne kwalifikacje i umiejętności kapitał ludzki, czyli osoby będące w przyszłości autorami opracowanych innowacji i nowoczesnych odkryć. Samorząd terytorialny, czyli administracja lokalna i regionalna inicjuje, koordynuje działania prorozwojowe, wnosi zamówienia publiczne na opracowywane innowacje i do tego oferuje różnorodne możliwości wsparcia działalności $B+R$. Z kolei sfera biznesu wnosi zdolność do podjęcia ryzyka, otwiera rynki zbytu i kanały dystrybucji orz co najważniejsze w dużej mierze finansuje aktywność innowacyjną.

Dla scharakteryzowania środowiska sprzyjającego innowacjom, użyć można koncepcji „złotego trójkąta”, gdzie na rzecz budowania zdolności innowacyjnych wysiłki łączą partnerzy z trzech sfer: biznesu, nauki, administracji. Przedstawiciele każdej z nich wnoszą do tego procesu określone zasoby i możliwości, oczekując dla siebie w zamian wymiernych korzyści ${ }^{11}$.

\section{BIBLIOGRAFIA}

Etkowitz H., The Triple Helix of University-Industry-Government. Implications for Policy and Evaluation, SISTER, „Working Paper”, 2002, no. 11.

\footnotetext{
${ }^{10}$ M. Nowak, M. Mażewska, Sz. Mazurkiewicz, op. cit.

${ }^{11}$ Ibidem.
} 
European Innovation Scoreboard 2003-2007, http://www.proinno-europe.eu/index. cfm?fuseaction=page .display\&topicID=5\&parentID=51, 29.06.2009 r.

European innovation scoreboard 2008. Comparative analysis of innovation Performance, European Communities, Luxembourg 2009, http://www.eis.eu/, 29.03.2010 r.

European Innovation Scoreboard 2009, European Communities, Luxembourg 2009, http://ec.europa.eu/enterprise/newsroom/cf/_getdocument.cfm?doc_id=5714, 23.02.2012 r.

Hall B. H., Policy for innovation: insights from economic research, http://www.vinnova.se/upload/dokument/VINNOVA_gemensam/Kalender/2008/Seminarium\%20 4\%2C\%2012\%20juni/4\%20juni\%20filmer\%2C\%20PPT/Sweden_4Jun2008_ Bronwyn\%20Hall.pdf, 14.07.2009 r.

European Innovation Scoreboard 2001, European Commission, Luxembourg 2001.

European Innovation Scorebard 2002, European Commission, Luxembourg 2002.

Innovation Union Scoreboard 2010, http://www.proinno-europe.eu/inno-metrics/page/ 1-executive-summary, 23.02.21012 r.

Innovation Union Scoreboard 2011, http://www.proinno-europe.eu/inno-metrics/page/ 1-executive-summary-0, 23.02.21012 r.

Matusiak K. B., Budowa powiqzań nauki z biznesem w gospodarce opartej na wiedzy, SGH, Warszawa 2011.

Mikołajczyk B., Zaręba M., Otoczenie instytucjonalne dla rozwoju innowacyjności $w$ Finlandii, „Studia Europejskie”, 2005, nr 3.

Nowak M., Mażewska M., Mazurkiewicz Sz., Wspótpraca ośrodków innorwacji z administracja publiczną, PARP, Łódź-Gdańsk-Kielce 2011, http://www.pi.gov.pl/PARPFiles/file/OIB/SOIB/Publikacje/PARP_BIOS_T25_broszura_Wspolpraca_z_admistracja.pdf, 24.06.2012 r.

Otoczenie instytucjonalne matych firm innowacyjnych, „Gazeta Innowacje”, nr 18, http:// imik.wip.pw.edu.pl/innowacje18/strona10.htm, 07.07.2009 r.

Porter M., Schwab K., The Global Competitiveness Report 2008-2009, World Economic Forum, Geneva 2008, http://www.weforum.org/pdf/GCR08/GCR08.pdf, 23.03.2010 r.

Prystrom J., Dziatalnośi innowacyjna a konkurencyjność polskich podmiotów gospodarczych, [w:] Czech-Rogosz J. (red.), Koniunktura gospodarcza a reakcje podmiotów gospodarujacych, Wydawnictwo Akademii Ekonomicznej w Katowicach, Katowice 2009.

Prystrom J., Innowacyjne determinanty funkcjonowania rynku pracy na przyktadzie gospodarki szwedzkiej, Oficyna Wydawnicza Politechniki Białostockiej, Białystok 2012. Reason for which enterprises did not carry out innovation activities 2002-2004, http:// www.scb.se/templates/tableOrChart_222609.asp, 04.07.2008 r.

Schumpeter J. A., The Theory of Economic Development, Galaxy Book, New York 1932. Schwab K., The Global Competitiveness Report 2010-2011, World Economic Forum, Geneva 2010, http:/www3.weforum.org/docs/WEF_GlobalCompetitivenessReport_2010-11.pdf, 21.02.2012 r. 